\title{
KERNIAL SINGH SANDHU
}

When, nearly forty years ago, I walked into a dusty, wind-swept classroom in what was then the University of Malaya to lecture on population growth and fertility among Southeast Asian peoples, I was not altogether happy to see at the back of the room a group of Indian students somewhat more advanced in age than the usual undergraduate. My wife to be, who had taught them in a previous term, had warned me that they were mature and politically knowledgeable fellows, most of whom had come late to the University after pursuing careers elsewhere and who delighted in verbal skirmishes with neophyte colonial lecturers. I cannot now remember all their names but among them certainly were James Puthucheary and Jamit Singh (familiar names to any Singaporean who remembers the 'fifties) and, of course, Kernial Singh. I survived that term although - incidentally - Kernial told me much later that his particular group much preferred my wife's lectures to mine: she was interested in what they knew, I was trying to discover what they didn't know. Whether this was true or not, it did not occur to me that among this group of dissidents was one who would become one of my closest friends.

It was not until Kernial's senior year in 1955 that I came to know him at all well. (For one thing, my game was tennis, rather than the hockey or cricket to which he was addicted.) In that year he joined a team of students engaged in a survey of padi production in Mukim Padang Pauh in Perlis. In my capacity as the supervisor of that survey, I paid several fairly extended visits to Kernial's group and stayed with them in the house they were renting. I remember being fascinated by the way in which a Perak Malay (who went on to become Minister of Education in the Federation Government), a Johor Malay of Banjarese descent, a Melaka Cantonese, a Singapore Hokkien, and a Johor Sikh adapted so readily to the exigencies of communal living in spite of their differing cultural backgrounds. What I recall mostly vividly about my visits to Padang Pauh were the raucous nights when the padi fields resounded to University of Malaya students songs. Naturally I had no idea that this was but the first of numerous occasions when I would visit with Kernial (in Singapore, both at Adam Park and earlier at Raffles Hall, where he was the warden, Kuala Lumpur, Segamat, London, and Vancouver) and he with me (in California, Chicago, and London).

Kernial was an uncommonly capable student and, as he specialized in my particular field of study, I suppose I can claim some small credit for guiding him to a first-class degree. But he himself gets all the credit for resisting the blandishments of the several companies and corporations that attempted to lure him into the business world. I am not at all sure what motivated him but it was clear at the time that he was determined to enter the academic 
profession, and neither chief executive officers nor Professor Dobby, at that time Acting Vice-Chancellor of the University of Malaya, were going to change his mind. There followed a Master's Degree from British Columbia and a doctorate from the University of London. I was instrumental in persuading Kernial to choose University College London, although I had left there before he arrived, and he pursued his studies under the direction of Professor Sir Clifford Darby. This was at once a rare privilege and an equally rare achievement for Sir Clifford accepted very few doctoral candidates and few of those whom he did accept survived the rigours of his supervision. I should also note that it is rare for the Cambridge University Press to publish doctoral theses, as it did in the case of Kernial's Indian in Malaya.

Our formal collaboration (as opposed to informal discussions) began in about 1970 with the preparation of a book on Early Malaysia and continued until the time of his death. Some of our efforts were on a substantial scale, many were comparatively minor; some resulted in publications, more simply proved impracticable for one reason or another or were abandoned or consigned to an indefinite future. Among these latter was an attempt to reconstruct the nineteenth and early twentieth-century development of Johor on which we embarked in the late 1960 s and which I found especially enjoyable even though it came to nothing. Kernial knew the region like the back of his hand. As we crisscrossed the state from village to village, he enlivened our investigations with anecdotes and interviews with people he had known years earlier. And very often we would find ourselves at the end of the day at Keluang, where Kernial for several years had taught school and where he still had friends eager to enliven our evenings. As the talk slid back and forth I felt that I was listening to the heart of historical Johor, whether we were in a coffee-shop in an old kangkar settlement, the hut of a tin-mining kongsi, or the home of a school teacher in Keluang. Kernial possessed the not-socommon ability to elicit meaningful information from all these people. The fact was, of course that he had transcended his cultural origins. Although he was, and remained a Sikh through and through (despite the lack of turban and beard), he had thoroughly assimilated to the world-wide culture of academia while possessing the common touch that enabled him to relate easily to people in all walks of life.

It goes without saying, that whatever his scholarly achievements, Kernial's most impressive and, it is to be hoped, most lasting monument is the Institute. He found it a fledging experiment with a dubious future and after two short decades left it the powerful and respected institution it is today. This was no job for a narrow disciplinary specialist. It required the Director to expand his academic competencies and raise his intellectual horizons in order to make the Institute a truly viable focus for research on contemporary Southeast Asia. Just how successful he was is amply attested by the diversity of programmes and publications currently sponsored by the Institute. I think 
it is remarkable that no one scanning these programmes would be able to deduce from them the Director's own academic training. Equally noteworthy is the circumstance that, despite the pressures of the Directorship, the administrator never betrayed the scholar. Both programmes and publications were maintained at a level of quality that puts some Southeast Asian Studies Centres in other parts of the world to shame. The same meticulous attention to detail was evident in our joint editorial efforts. After three weeks in my house in Chicago going over the text of our Melaka volumes for twelve hours a day, I was more than ready to countenance an occasional ambiguity, or indeed infelicity, in a paper. But Kernial wouldn't hear of it, and we would often spend the rest of the evening trying to contact an author in some distant part of the world.

Many of you will know that our collaboration was not an expediential business arrangement intended to facilitate a common research agenda but a close friendship that developed over nearly $\mathbf{4 0}$ years, and involved both our families. To some it may seem anomalous that two fellows from respectively Gloucestershire and Johor - which surely had little in common, especially some fifty or so years ago - should have established such an enduring rapport. I guess it reflected a commonality of fundamental values and a shared philosophy of life. But this does not mean that we always saw eye to eye, either in political or academic matters. In fact, it was usually the opposite: we fed off our differences, and the real pay-offs to our alternating visits to Singapore and Chicago were not the advancement of our projects but rather the delight of riding our hobbyhorse in new contests.

It was a long road for the lad from Segamat who, dispatched to Australia to study chemical engineering, got no farther than Keluang; who began as a school teacher and became a professor in a North American university; and who, for compelling domestic reasons, in mid-life began a new career building the world's most prestigious centre of contemporary Southeast Asian studies. If, as the founder of the Sikh faith said, "Man shall be saved by his works alone. God will not ask a man his tribe or sect, but what he has done", Kernial Singh Sandhu will have nothing to fear. And Margo and I are proud to have been witnesses to that pilgrimage but greatly saddened that it has prematurely reached its goal.

Paul Wheatley 